\title{
CITRA DIRI DAN POPULARITAS ARTIS
}

\author{
Esther Meilany Pattipeilohy \\ Le Moesiek Revole
}

\begin{abstract}
ABSTRAK
Media massa sebagai media informasi publik menjadi media promosi bagi artis untuk mendapatkan popularitas dan keuntungan secara finansial. Seringkali artis menuntut dirinya sendiri untuk kooperatif dengan wartawan, awak media yang akan menampilkan realitas simbol-simbol yang diterimanya pada saat melakukan wawancara. Bagaimana artis memahami citra dirinya yang ditampilkan di media massa, bagaimana artis mempersiapkan penampilan citra dirinya di hadapan wartawan (back stage region), bagaimana artis menampilkan citra dirinya di hadapan wartawan (front stage region), dan bagaimana artis memahami popularitasnya di publik sebagai dampak dari pemberitaan yang dibingkai wartawan di media massa (out stage region) menjadi rumusan masalah dalam penelitian ini. Untuk mengungkapkan pengelolaan kesan artis dalam media massa, penelitian ini menggunakan metode kualitatif dengan pendekatan teori dramaturgi. Hasil penelitian menunjukkan bahwa yang paling mempengaruhi citra diri artis adalah orang-orang sekitar yang berinteraksi dengan dirinya, karena interaksi tersebutlah yang akan menjadi realita. Realita tersebut harus mampu dibingkai artis menjadi bagian dari citra dirinya. Sebelum berhadapan dengan wartawan untuk diwawancara, artis melakukan beberapa persiapan untuk menampilkan citra diri yang positif di hadapan wartawan. Artis memahami sepenuhnya makna popularitas bagi dirinya. Citra diri yang ditampilkan oleh artis, jika dibingkai secara positif oleh wartawan dalam berita di media massa, maka akan memberi kesan positif juga oleh publik. Jika sebaliknya, maka publik juga yang akan menolaknya. Berita di media massa membawa dampak popularitas yang besar bagi artis. Artis membutuhkan popularitas untuk dapat bertahan dalam menjalankan profesinya. Selain itu, artis juga mendapatkan berbagai keuntungan baik secara materi maupun immateriil sebagai dampak dari popularitas yang diperolehnya. Artis selalu berupaya memelihara hubungan baik dengan wartawan sebagai mitra kerjanya.
\end{abstract}

Kata-kata Kunci: Citra diri, dramaturgi, artis, wartawan, media massa

\section{SELF-IMAGE AND POPULARITY OF ARTISTS}

\begin{abstract}
The mass media as a medium of public information become a campaign media for the artists to gain popularity and financial gains. Artist requires herself to cooperate with journalists, media crews, that will show the reality of symbols received at the time of the interview. Problem formulation of this research are: how the artist understands on how his/her image being displayed in the media, how the artists prepare him/ herself to show his/her image in the presence of reporters (back stage region), how the artist displays his/her image in front of reporters (front stage region), and how the artists understand the popularity in public is a result of news being framed in the mass media by reporter (out stage region). This research uses qualitative method with dramaturgical theory approach to reveal artist's impression management in the mass media. The results show that most influential factor for the self-image of the artists is how they interact with people around them, because the interaction itself is a reality. The reality is framed by the artists to be a part of his/ her image. Prior to interview with the reporter, the artist did some preparation to display his/her positive selfimage. Artists fully understand the meaning of popularity for themselves. Self-image being displayed by the artist, if framed positively by journalists in the news for the media, will give a positive impression towards the public and vice versa. The news in the media brings great effect to the artist's popularity, which is needed to survive in their line of work. Furthermore, the artists will get various benefits and profits as the result of the popularity gained, so in other words, the artists ought to maintain good relations with reporters as their partner.
\end{abstract}

Keywords: Self-image, dramaturgy, artist, reporter, mass media

Korespondensi: Le Moesiek Revole. Jln. Daan Mogot Raya No. 2, Kompl. Perkantoran SPBU Coco Lt. 2, Grogol, Jakarta Barat 11460.Email: ellapatti.2000@gmail.com 


\section{PENDAHULUAN}

Artis sangat memahami peran media untuk perkembangan karirnya. Banyak artis yang kemudian memanfaatkan media massa untuk berbagai tujuan seperti menaikkan reputasi, membuat sensasi agar namanya tetap populer, atau memanfaatkan media sebagai media promosi untuk kepentingan bisnisnya, dan lainlain. Semakin banyak sorotan yang ditujukan media kepada mereka, semakin mendongkrak popularitas sang artis. Popularitas ini yang kemudian menjadi modal bagi artis tersebut untuk mendapatkan tawaran manggung dan atau penawaran kesempatan lain yang memberikan keuntungan secara finansial. Di sini, artis seringkali menuntut dirinya sendiri untuk kooperatif dengan media massa.

Media massa bekerja untuk menyampaikan informasi. Bagi khalayak, informasi itu dapat membentuk, mempertahankan atau meredefinisikan citra. Menurut Mc.Luhan (dalam Rakhmat, 2008: 224), media massa adalah perpanjangan alat indra kita. Dengan media massa, kita memperoleh informasi tentang benda, tempat yang tidak kita alami secara langsung, maupun figur-figur tertentu. Realitas yang ditampilkan media adalah realitas yang sudah diseleksi - realitas tangan kedua (second hand reality). Wartawan adalah orang yang kemudian menampilkan realitas simbolsimbol yang diterimanya pada saat melakukan wawancara.

Pemilihan judul pada penelitian ini dimaksudkan untuk menggambarkan bahwa penelitian ini juga mencakup hal-hal yang telah diteliti sebelumnya, tetapi dengan sudut pandang yang lebih luas, artinya hasil dari penelitian-penelitian sebelumnya dipergunakan peneliti sebagai bagian dari analisis yang peneliti lakukan.

Berdasarkan latar belakang masalah seperti yang dikemukakan diatas, maka masalah yang dapat dirumuskan sebagai berikut: "Bagaimana pembentukan citra diri artis di media massa dan popularitasnya di publik?". Dari fokus penelitian di atas, maka identifikasi masalah yang dirumuskan adalah (1) Bagaimana artis memahami citra dirinya yang ditampilkan di media massa?, (2) Bagaimana artis mempersiapkan penampilan citra dirinya di hadapan wartawan (back stage region)?, (3) Bagaimana artis menampilkan citra dirinya di hadapan wartawan (front stage region)?, dan (4) Bagaimana artis memahami popularitasnya di publik sebagai dampak dari pemberitaan yang dibingkai wartawan di media massa (out stage region)?

Adapun maksud dari penelitian adalah untuk mengkaji bagaimana memahami citra diri artis yang ditampilkan di media massa, mengerti persiapan artis dalam menampilkan citra dirinya di hadapan wartawan, mengerti penampilan citra diri artis di hadapan wartawan, dan memahami popularitas artis di publik sebagai dampak dari pemberitaan yang dibingkai wartawan di media massa.

Berdasarkan pada maksud penelitian diatas yang menjadi tujuan penelitian ini adalah untuk mengkaji bagaimana (1) Citra diri artis yang ditampilkan di media massa, (2) Persiapan artis dalam menampilkan ditra dirinya di media massa, (3) Penampilan artis dalam menampilkan citra dirinya di media massa, (4) Pemahaman artis mengenai popularitasnya di publik sebagai dampak dari pemberitaan yang dibingkai wartawan di media massa.

Mengacu pada harapan-harapan yang telah diungkapkan dalan tujuan penelitian, hasil akhir dari penelitian ini adalah berupaya mengetahui relatif mendalam tentang citra diri artis di media massa dan dampak popularitasnya akibat pemberitaan tersebut. Bagi perkembangan Ilmu Komunikasi, penelitian ini diharapkan dapat menambah wacana tentang penggunaan simbolsimbol dalam komunikasi oleh individu sebagai bagian dari upaya interpretasinya terhadap lingkungan sekitar, pengaruh simbol-simbol tadi terhadap perilaku individu, dan komunikasi interpersonal individu mampu memperkuat hubungan.

Secara praktis, hasil penelitian ini diharapkan dapat memberi manfaat langsung dan tidak langsung dalam konteks mengungkapkan realitas sosial tentang kehidupan artis yang sesungguhnya, dan sebagai acuan kontekstual dalam memahami kehidupan sosial artis dan pola komunikasi yang dikembangkan antara artis dan wartawan terhadap profesinya masingmasing.

\section{METODE PENELITIAN}

Metode penelitian berhubungan dengan teori penelitian yang akan digunakan dan menggambarkan proses penelitian, model 
apa yang akan digunakan oleh peneliti untuk menyelesaikan permasalahan yang akan diteliti. Metode adalah proses, prinsip, dan prosedur yang akan digunakan untuk mendekati problem dan mencari jawaban. Dengan ungkapan lain metodologiadalah suatupendekatanumumuntuk mengkaji topik penelitian. Penggunaan metode kualitatif diharapkan mampu menyelidiki lebih mendalam terhadap fokus yang diamati dengan seksama, sebab peneliti melibatkan diri dan mengamati kehidupan mereka sehari-hari, mendengar mereka berbicara tentang dirinya dan pengalaman mereka sendiri.

Berdasarkan latar belakang, identifikasi masalah, dan paradigma teori dengan merujuk pada teori fenomenologis, maka penelitian dengan mengungkapkan pengelolaan kesan artis dalam media massa menggunakan metode kualitatif dengan pendekatan teori dramaturgi. Dramaturgi sebenarnya berada di bawah payung perspektif yang lebih besar yang sering disebut perspektif fenomenologis atau perspektif interpretif (Mulyana, 2006: 59). Oleh Mulyana dijelaskan bahwa perspektif seringkali disebut sebagai pendekatan fenomenologi.

Jenis penelitian yang digunakan dalam penelitian ini adalah pendekatan kualitatif dengan jenis penelitian fenomenologis. Pada dasarnya fenomenologi cenderung menggunakan paradigma penelitian kualitatif sebagai landasan metodologisnya. Penelitian dengan menggunakan metode kualitatif dengan pendekatan fenomenologis menjadi sangat relevan untuk memahami bagaimana artis berupaya untuk membentuk citra diri yang positif di media massa. Popularitas yang kemudian dihasilkan dari pengembangan citra diri tersebut kemudian menjadi aset terbesar seorang artis dalam karir keartisannya.

Alfred Schutz adalah orang pertama yang menerapkan fenomenologi dalam penelitian ilmu sosial. Schutz mengawali pemikirannya dengan mengatakan bahwa objek penelitian ilmu sosial pada dasarnya berhubungan dengan interpretasi terhadap realitas (dalam Kuswarno, 2009: 38). Jadi peneliti harus membuat interpretasi terhadap realitas yang diamati. Orang-orang saling terikat satu sama lain ketika membuat interpretasi ini. Menurut Lofland dan Lofland, sumber data utama dalam penelitian kualitatif adalah kata-kata, dan tindakan, selebihnya adalah data tambahan seperti data dokumen, dan lain-lain. (Moleong, 2006: 157).
Dalam melakukan pencatatan data hasil wawancara, peneliti melakukan kualifikasi apakah informan memberikan jawaban atas pertanyaan yang diajukan atau keterangan yang tidak diminta. Juga diperhatikan situasi ketika informan memberikan jawaban, apakah ketika sedang berdua saja dengan peneliti atau ketika ada orang lain yang disekitarnya.

Proses penyimpanan data (data storing) merupakan tahap terakhir dari proses Data Collection Circle, sebelum memulainya lagi dengan penentuan tempat atau individu (locating site/individuals), untuk pengumpulan data ulang.

Penelitian ini dilakukan di kota Jakarta dengan pertimbangan bahwa rata-rata artis dan media massa nasional bertempat tinggal utama di Jakarta. Dari hasil survei yang dilakukan peneliti selama satu tahun sebelum terjun melakukan penelitian, peneliti menentukan 8 orang yang layak dijadikan informan utama dalam penelitian ini. Informan-informan tersebut terdiri dari 4 orang artis penyanyi perempuan, 1 orang manager artis, 1 orang asisten artis, serta 2 orang sisanya adalah wartawan media massa baik elektronik TV dan internet.

Proses pendekatan yang dimaksud adalah apa yang disebut Creswell sebagai "Gaining Acces and Making Rapport." Mendekati artis bukanlah hal yang mudah, apalagi bagi orang yang tidak punya akses sebelumnya, sehingga dibutuhkan kerja sama dengan pihak-pihak yang cukup dekat dengan mereka.

Untuk sebuah studi fenomenologis, kriteria informan yang baik adalah: "all individuals studied represent people who have experienced the phenomenon" (Creswell, 1998: 118). Jadi lebih tepat memilih informan yang karena pengalamannya dia mampu mengartikulasi pengalaman dan pandangannya tentang sesuatu yang dipertanyakan. Dalam penelitian ini, peneliti hanya mengambil empat orang artis penyanyi perempuan yang dianggap dapat merespresentasikan kebutuhan penelitian ini, yaitu Krisdayanti, Maia Estianty, Julia Perez, dan Yuni Shara.

Proses analisis data dimulai dengan menelaah seluruh data yang tersedia dari berbagai sumber, yaitu dokumen, wawancara, observasi, dan alat-alat fisik. Data yang dihasilkan dari berbagai sumber tersebut akan sangat banyak. Analisis dilakukan secara terus menerus semenjak pengumpulan data. 
Setelah data terkumpul dan dirasa cukup untuk pembuktian penelitian, peneliti melakukan pengolahan data. Kegiatan pengolahan data umumnya terdiri dari analisis data dan penafsiran data. Dalam penelitian ini hanya akan dilakukan penafsiran data.

Setelah dilakukan analisis data dan penafsiran data, selanjutnya adalah langkah untuk memeriksa keabsahan data. Pemeriksaan terhadap keabsahan data pada dasarnya selain digunakan untuk menyanggah balik apa yang dituduhkan kepada penelitian kualitatif yang mengatakan tidak ilmiah, juga merupakan sebagian unsur yang tidak terpisahkan dari tubuh pengetahuan penelitian kualitatif.

Penelitian ini dilakukan melalui proses dalam beberapa tahap yang masing-masing tahap memiliki spesifikasi tersendiri. Tahap pertama adalah penelitian pendahuluan yang dilakukan selama satu tahun terhitung dari 18 Januari 2010 hingga Desember 2010. Penelitian pendahuluan bertujuan untuk melakukan pencatatan data tentang profil para artis dan wartawan yang akan dijadikan informan. Penelitian ini sendiri berlangsung sejak bulan Januari 2011 hingga Desember 2012.

\section{HASIL DAN PEMBAHASAN}

Secara umum, penelitian ini mengambil industri hiburan dengan artis sebagai pelaku utamanya. Seperti diketahui, artis atau selebritis tidak terbatas pada industri hiburan tertentu saja, tetapi yang bersifat umum dan atau general. Pada penelitian ini, peneliti masuk dalam lingkungan profesi artis yang spesifik yaitu lingkungan artis penyanyi. Pada dasarnya, peneliti melihat bahwa pola pergaulan yang berbeda antara artis penyanyi dengan artis non penyanyi seperti artis sinetron, dan atau artis dari industri film dan lain-lain. Hal ini disadari sebagai bentuk kewajaran, mengingat aktifitas profesinya yang berbeda.

Meskipun kelihatannya pekerjaan sebagai penyanyi dinilai tidak sesulit seperti pemain sinetron dan atau film, tetapi memilik tantangan tersendiri. Penyanyi sangat tergantung kepada lagu sebagai produk yang dihasilkannya. Jika lagu tersebut diterima pasar dengan baik (laku di pasaran), maka dapat dipastikan jika penyanyi tersebut akan terdongkrak popularitasnya. Tetapi jika lagu yang dinyanyikan kurang laku di pasaran, maka popularitas artis yang bersangkutan juga akan stagnan. Oleh sebab itu, banyak penyanyi yang kemudian menyanyikan lagu-lagu yang sudah dikenal, atau pernah populer di masa lalu (recycle). Salah satu penyanyi yang bahkan menjadikan lagu-lagu lama sebagai spesialisasi dia dalam bernyanyi adalah Yuni Shara.

Informan pertama yang menjadi nara sumber pada penelitian ini adalah Yuni Shara. Yuni Shara lahir di Malang, 3 Juni 1972 dan terlahir dengan nama Wahyu Setyaning Budi. Lahir sebagai anak pertama dari tiga bersaudara, Yuni Shara juga memiliki adik perempuan yang juga menjadi artis penyanyi bernama Krisdayanti, yang juga menjadi informan pada penelitian ini.

Informan kedua yang menjadi nara sumber pada penelitian ini adalah Krisdayanti. Krisdayanti adalah adik kandung dari artis Yuni Shara yang menjadi informan pertama peneliti. Krisdayanti lahir di Malang, 24 Maret 1975 sebagai anak kedua dari tiga bersaudara.

Informan ketiga peneliti adalah Maia Estianty. Maia Estianty lahir di Surabaya, Jawa Timur, 27 Januari 1976 dengan nama Maya Estianty sebagai anak kelima dari enam bersaudara. Maia Estianty saat ini dikenal sebagai seorang pencipta lagu, penyanyi perempuan, musisi, dan pengusaha di Indonesia.

Informan keempat peneliti atau informan terakhir pada penelitian ini adalah Julia Perez. Julia Perez atau disingkat Jupe lahir di Jakarta, 15 Juni 1980 dengan nama Yuli Rachmawati. Ia dikenal sebagai penyanyi dangdut, presenter, DJ, model, pemain sinetron dan pemain film. Ia terkenal gemar berfoto seksi sehingga dijuluki "bom seks" Indonesia.

Berikut adalah hasil penelitian dan pembahasan bagaimana artis memahami citra diri yang ditampilkannya di media massa:

Peneliti mendapatkan beberapa indikator bagaimana artis memahami citra dirinya di depan wartawan media massa, yaitu: (1) Artis sangat berhati-hati dalam mengelola citra dirinya di depan wartawan, karena akan mempengaruhi kesan yang ditampilkan di media massa, terutama karena artis yang menjadi informan pada penelitian ini pernah mengalami pengalaman yang buruk dengan berita negatif mengenai dirinya di media massa. Artis berusaha menampilkan citra dirinya yang sesuai dengan realita kehidupan sehari-hari. Artis memahami, jika citra diri yang ditampilkannya 
adalah rekaan semata atau palsu, maka cepat atau lambat publik dapat mengetahui realita tersebut. Dampaknya akan buruk bagi citra dirinya, karena artis yang bersangkutan akan dituduh melakukan kebohongan publik, dan (2) Jika berita mengenai artis yang bersangkutan semakin banyak mengisi media massa, maka dimanapun artis berada, selalu ada wartawan yang bersedia meliput. Ini akan sangat baik, jika di masa depan mereka membutuhkan wartawan untuk membuat berita yang memuat kepentingan pribadi artis yang bersangkutan. Misalnya untuk kepentingan usaha (bisnis) dan lain-lain;

Dalam memaknai citra dirinya, artis memiliki polanya masing-masing. Hal ini terkait erat dengan kebutuhan industri hiburan itu sendiri. Masing-masing informan yang menjadi objek penelitian memiliki citra diri (image) yang khas di publik, yang terbentuk akibat paparan media massa.

Yuni Shara dikenal sebagai artis senior yang ramah, profil ibu rumah tangga yang sederhana, tetapi juga memiliki keberanian bersikap terutama setelah diketahui lama berhubungan cinta dengan artis yang berselisih usia 15 tahun lebih muda dari dirinya. Krisdayanti dikenal sebagai diva, penyanyi dengan kemampuan lengkap: mulai dari penampilan yang selalu jadi trend, hingga teknik menyanyi yang sangat baik. Tapi KD dikenal memiliki kelemahan moral karena pernah diberitakan selingkuh dari pasangan hidupnya lebih dari satu kali. Bahkan untuk kasus rumah tangganya yang terbaru, Krisdayanti yang tadinya menolak diberitakan selingkuh dengan seorang pria, akhirnya malah menikahi pria tersebut dan kini memiliki dua orang anak dari pria yang bersangkutan.

Maia Estianty dikenal sebagai musisi perempuan yang punya kemampuan bermusik yang hebat, dan juga sebagai perempuan kuat yang dulunya teraniaya oleh suami, tapi membuktikan diri sanggup bangkit dan keluar dari keterpurukan. Julia Perez dikenal sebagai "bom sex" karena gemar berpakaian seronok, tetapi juga sebagai perempuan yang kuat karena gigih mendapat restu ibu untuk hubungan pribadinya dengan seorang atlit sepak bola. Julia Perez juga dikenal sangat optimis memandang hidupnya meskipun sempat mendapat berbagai persoalan, mulai dari kasus pencekalan di beberapa daerah, hingga kasus hukum terbaru yang menyebabkan dia harus masuk penjara selama tiga bulan. Masing-masing artis memiliki citra diri yang kuat di hadapan publik, terutama terkait dengan kehidupan pribadi dibalik karir bermusiknya.

Para artis ini sangat memahami bahwa citra dirinya di depan publik terbentuk sematamata justru karena kehidupan pribadinya yang terekspos di media massa. Oleh sebab itu, lepas dari berbagai kontroversi dalam kehidupan pribadinya, artis sangat menjaga citra dirinya yang sudah terbentuk di publik.

Berikut adalah hasil penelitian dan pembahasan bagaimana artis mempersiapkan citra dirinya di hadapan wartawan (back stage area): Peneliti mendapatkan beberapa upaya artis dalam mempersiapkan citra diri yang ingin dibentuknya di hadapan wartawan. Artis sangat memahami, jika persiapan sebelum bertemu wartawan dan melakukan wawancara penting untuk dilakukan. Berikut beberapa upaya artis sebelum melakukan wawancara: (1) Selalu berusaha tampil rapi dan merias diri terlebih dahulu sebelum bertemu wartawan; (2) Menenangkan diri dan berusaha berada dalam kondisi emosi yang stabil; dan (3) Berdiskusi dengan manajemen untuk menampilkan citra diri yang positif di hadapan wartawan.

Artis sangat memahami mengenai pentingnya merias diri agar tampil lebih cantik di depan wartawan, karena ini akan mempengaruhi wartawan dalam membuat berita tentang dirinya. Hal ini berlaku untuk seluruh informan. Keempat informan artis pada penelitian ini secara terbuka menyatakan hal itu kepada peneliti.

"Kalau depan wartawan biasanya aku nggak pernah mau kalau nggak make up. Pokoknya kalau aku muncul di TV, orang lihat kemasannya bagus. Kalau kita keluar kan itu seperti iklan, marketing. Jadi aku nggak sembarangan ketika aku keluar di TV. Kadang-kadang kalau aku ngomong, aku berpikir dampaknya apa. Kalau aku ngomong begini dampaknya apa."

(Wawancara Julia Perez)

"Ya pernah lah. Dulu aku nggak seneng ke salon, ya apa adanya. Kadang-kadang orang memandang, koq artis gini banget, biasa. Tapi setelah mempelajari dari tahun ke tahun, packaging itu sangat penting untuk seorang public figure. Perempuan itu 
penting. Apalagi saya harus bersyukur, 20 tahun menyanyi, masih dipanggil kesana kemari, menjemput rejekinya anak-anak. Paling nggak, kalau saya nggak menarik, mungkin orang nggak ada yang panggil saya. Orang yang suaranya lebih bagus banyak. Yang pinter entertain juga banyak koq."

(Wawancara Yuni Shara)

Bahkan, Maia Estianty memiliki standar sendiri untuk setiap penampilannya di media massa, terutama media massa cetak. Peneliti menemukan, Maia selalu meminta seorang make up artis terkenal bernama Mia untuk selalu merias dirinya ketika akan melakukan wawancara atau difoto untuk kebutuhan media massa cetak.

"Karena satu, gua percaya sama bu Mia, kedua gua males dandan, ketiga gua comfort aja sama dia, karena kalau sama dia gua pasti save."

(Wawancara Maia Estianty)

Ketika peneliti menanyakan mengapa Maia memperlakukan media massa cetak berbeda, maka Maia menjawab lugas,

"Kalo liat TV kan semenit dua menit tiga menit. Tapi kalau media cetak kan disimpen.

Kalau TV kan 1 jam selesai. Karena cetak lebih terdokumentasi, usianya lebih lama." (Wawancara Maia Estianty)

Hal ini tepat seperti yang dikemukakan oleh Goffman (Poloma, 2004: 231) bukan memusatkan perhatiannya pada struktur sosial, melainkan pada interaksi tatap-muka atau kehadiran bersama (Co-presence). Interaksi tatap-muka itu dibatasinya sebagai "individuindividu yang saling mempengaruhi tindakantindakan mereka satu sama lain ketika masingmasing berhadapan secara fisik".

Artis beranggapan jika penampilan lahiriah mereka cukup penting di media massa. Bahkan para informan artis ini menyatakan, jika hal itulah yang pertama kali mereka perhatikan setiap kali mereka melihat berita tentang diri mereka di media massa.

Berikut adalah hasil penelitian dan pembahasan bagaimana artis ketika menampilkan citra dirinya dalam wawancara di hadapan wartawan (front stage region): (1) Berusaha selalu tersenyum dan dalam kondisi emosi yang stabil ketika bertemu wartawan; (2) Berusaha mengatur ritme pembicaraan ketika berbincang-bincang dengan wartawan, sehingga setiap pernyataan yang diucapkan dapat ditangkap dengan jelas oleh wartawan, dan (3) Berusaha mengatur kalimat sehingga kalimat yang dikatakan cukup bijaksana.

Upaya-upaya tersebut biasanya juga didukung oleh manajemen artis yang bersangkutan. Beberapa fenomena yang peneliti dapatkan dari manajemen artis dalam penelitian ini adalah: (1) Manajemen berusaha mengatur wartawan untuk tertib sebelum bertemu dengan artis; (2) Manajemen bertanya kepada wartawan daftar pertanyaan yang akan ditanyakan kepada artis yang bersangkutan. Jika ada pertanyaan yang kurang berkenan, maka manajemen akan meminta wartawan yang

\section{BACK STAGE AREA}

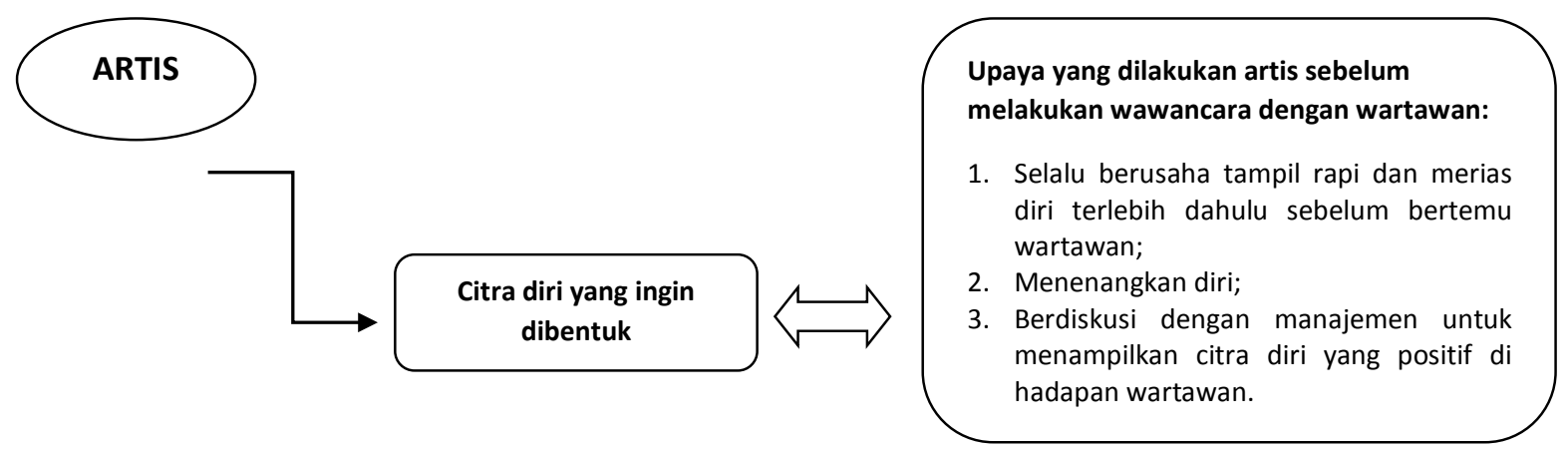

BACK STAGE AREA 
bersangkutan untuk membatalkan pertanyaan tersebut atau menggantinya dengan pertanyaan lain, (3) Manajemen mendampingi artis yang bersangkutan ketika sedang melakukan wawancara; dan (4) Manajemen bertindak sebagai time keeper atau pengatur waktu durasi tanya jawab antara artis yang bersangkutan dengan wartawan.

Masing-masing informan yang peneliti teliti dalam penelitian ini juga memiliki cara masingmasing untuk mempertahankan citra diri yang mereka inginkan, terutama ketika berhadapan dengan wartawan. Mereka memahami, bahwa melalui wartawan yang bertemu dengan mereka secara langsunglah, citra diri mereka terbentuk di media massa. Mereka menyadari, berita mengenai mereka tergantung bagaimana mereka bersikap. Maia Estianty dengan waktu karir 10 tahun memilih untuk bersikap kompromi dengan wartawan, meski dengan demikian ia harus menyembunyikan citra diri yang sesungguhnya.

"Ehmm.. tetep kita harus berlaku dan bersikap seperti apa yang publik mau. Sebenarnya ada (tekanan psikologis) sih, karena kita nggak jadi manusia yang apa adanya. Cuman tidak semua harus diungkap dengan gaya kita yang belum tentu bener. Kita harus bener-bener belajar, kalau di media kita harus berbicara seperti apa. Apa yang harus diungkap, apa yang tidak perlu diungkap."

(Wawancara Maia Estianty)

Hal tersebut tidak berlaku untuk Yuni
Shara yang sudah berkarir sebagai artis diatas 25 tahun.

"Saya nggak suka dibuat-buat. Tapi kalau memang keadaannya begitu ya ayo aja. Sejauh tidak mengganggu kegiatan saya." (Wawancara Yuni Shara)

"Sekarang ada artis infotainment, kebetulan saya bukan kategori itu. Saya nggak perlu bawa bawa infotainment kemana-mana, karena penonton TV kita sekarang pinter, mereka akan muak dengan pemberitaanpemberitaan seperti itu. Saya terus terang malah punya selling point tinggi, tapi masyarakat yang pinter-pinter itu akan mencemooh kita kan? Itu juga saya dapat dari pengalaman-pengalaman saya."

(Wawancara Krisdayanti)

Pada kenyataannya, ada perbedaan sikap bagaimana membentuk citra diri di depan media dari artis-artis senior seperti Yuni Shara dan Krisdayanti, dengan artis-artis yunior seperti Maia Estianty dan Julia Perez. Tetapi pada akhirnya mereka menyadari, bahwa kehatihatian dalam bersikap menjadi hal yang paling penting ketika berhadapan dengan wartawan, terutama karena masing-masing artis pernah diberitakan dengan berita kontroversi.

Dengan konsep dramaturgis dan permainan peran yang dilakukan oleh artis, terciptalah suasana-suasana dan kondisi interaksi antara artis dan wartawan yang kemudian memberikan wartawan makna tersendiri untuk dibingkai dalam berita yang mereka hasilkan di media

\section{FRONT STAGE AREA}

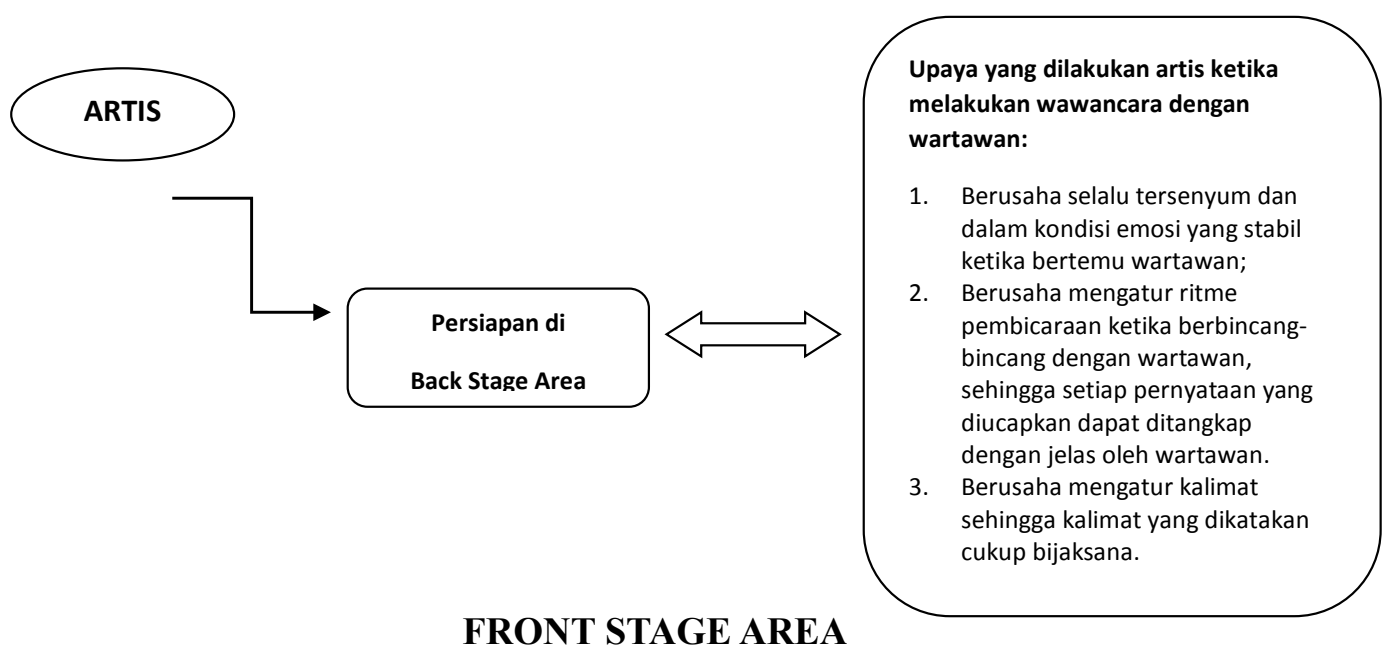


massa. Munculnya pemaknaan ini sangat tergantung pada latar belakang sosial artis itu sendiri.

Berikut adalah hasil penelitian dan pembahasan bagaimana artis memahami popularitasnya di publik sebagai dampak dari pemberitaan yang dibingkai wartawan di media massa (out stage area). Artis memiliki berbagai pemahaman tentang popularitas. Berikut adalah beberapa pemahaman artis tentang popularitas yang diraih sebagai dampak dari pemberitaan di media massa yang dibingkai oleh wartawan: (1) Popularitas adalah dampak dari pemberitaan yang dibingkai oleh media massa; (2) Bagi artis yang tergolong senior karena masa karir yang lama, popularitas bukan hal yang utama lagi dalam berkarir; (3) Popularitas adalah hasil kerja keras, dedikasi, dan loyalitas terhadap pekerjaan.

Artis memahami jika popularitas adalah dampak yang diraih dari pemberitaan tentang dirinya dimedia massa. Jika berita di media massa memuat berita yang positif, maka dampaknya juga akan positif. Tetapi jika sebaliknya, maka dampak negatiflah yang akan didapat. Beberapa dampak dari citra diri artis yang positif di media massa adalah bertambahnya tawaran pekerjaan show, kesempatan bertemu berbagai kalangan masyarakat, peluang pendapatan lain misalnya dari iklan, dan lain-lain, serta penambahan jumlah fans yang signifikan. Selain itu, beberapa dampak dari citra diri artis yang negatif di media massa yaitu pemutusan hubungan kerja dengan pihak ketiga, kehilangan kesempatan mendapatkan penghasilan lewat iklan, off air, dan lain-lain, serta kehilangan fans.

Artis juga berupaya untuk meraih maupun mempertahanan popularitas yang sudah dicapai.
Beberapa upaya yang dilakukan artis sebagai bentuk upaya tersebut yang berhasil didapat peneliti dalam penelitian ini adalah: (1) Artis menghasilkan produk lagu-lagu terbaru yang berkwalitas agar dapat diterima dengan baik oleh publik; dan (2) Artis memperlakukan wartawan sebagai rekan kerja dalam berkarir di industri hiburan.

Artis sangat memahami peran popularitas dalam karirnya. Artis menyadari bahwa popularitas tidak daatang dengan otomatis, tetapi juga melalui proses yang panjang. Kerja keras dalam berkarir menjadi salah satu upaya yang dilakukan artis dalam upayanya meraih popularitas yang ingin diraih. Hal ini memang dapat dijelaskan melalui teori fenomenologi yang memang bertujuan untuk mengetahui dunia dari sudut pandang orang yang mengalaminya secara langsung atau berkaitan dengan sifat-sifat alami pengalaman manusia dan makna yang ditempelkan padanya. Seperti yang diungkapkan oleh Julia Perez dalam wawancaranya dengan peneliti.

"Bekerja keras, berdoa dan berusaha, dan selalu buka wawasan luas. Buka internet, aku juga liat-liat artis luar. Kalau baca koran kalau jadi bupati ya, hahaha. Jadi belajar sesuai dengan porsinya. Kalau lu di entertain, ya pelajari dari orang-orang yang udah sukses, dari orang-orang yang mempunyai predikat-predikat yang baik. Aku ambil sisi baiknya. Jadi aku percaya, kalau kita mau pasti bisa. Kalau modal badan pasti selesai. Hidup itu terlalu singkat untuk dihancurin gitu aja. Selalu cari yang terbaik. Kadang-kadang kita nggak mau tapi ya harus terima. Bagaimana kita

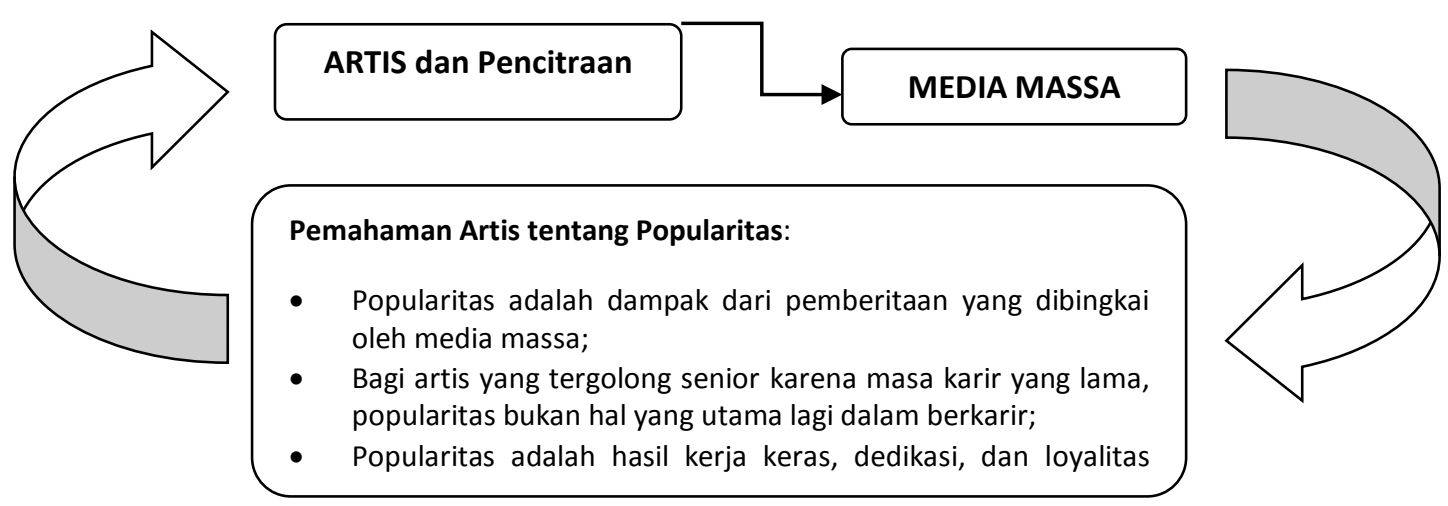


menyikapinya dengan benar, dengan tidak sombong. Kalau pun mencong dikit, ya nggak mencong-mencong banget. Ujungujungnya sikap."

(Wawancara Julia Perez)

Hal ini selaras dengan George Herbert Mead yang berpendapat bahwa manusia merupakan makhluk yang paling rasional dan memiliki kesadaran akan dirinya. Konsep diri menurut George Herbert Mead, pada dasarnya terdiri dari jawaban individu atas pertanyaan "Siapa Aku."

Artis sangat memahami, jika citra diri yang ingin diraih harus melalui proses pembentukan terlebih dahulu. Proses pembentukan itu meliputi persiapan sebelum melakukan wawancara, dan ketika melakukan wawancara di hadapan wartawan. Citra diri yang ditangkap oleh wartawan itulah yang kemudian akan dikembangkan oleh wartawan dalam berita yang dibingkainya di media massa.

Artis juga memahami, jika berita mengenai dirinya di media massa akan berdampak secara psikologis bagi publik. Berita dengan citra yang positif akan menghasilkan dampak popularitas yang positif. Sebaliknya, jika berita memuat citra negatif, maka akan menghasilkan dampak popularitas yang negatif pula. Beberapa dampak dari citra diri artis yang positif di media massa adalah bertambahnya tawaran pekerjaan off air, kesempatan bertemu berbagai kalangan masyarakat, diantaranya pengusaha dan atau pejabat publik, peluang mendapatkan kesempatan menambah penghasilan lain misalnya iklan, dan lain-lain, serta penambahan jumlah fans yang signifikan

Selain itu, beberapa dampak dari citra diri artis yang negatif di media massa yaitu pemutusan hubungan kerja dengan pihak ketiga, kehilangan kesempatan mendapatkan penghasilan lewat iklan, off air, dan pemasukan lain-lain, dan kehilangan fans.

Artis juga memahami jika citra diri yang ingin diraih harus senantiasa dipelihara dengan konsisten. Konsistensi penting agar publik tidak bingung dalam menilai citra yang ingin ditampilkan. Ada beberapa cara yang ditempuh artis untuk mempertahankan konsistensi citra dirinya, diantaranya dengan tampil berkala di media massa.

Akibat dari citra diri yang dibingkai oleh wartawan dalam berita di media massa, dampaknya adalah popularitas artis yang meningkat di publik. Popularitas ini juga berperan penting dalam karir keartisan. Berikut adalah beberapa manfaat popularitas bagi artis yang berhasil peneliti dapatkan di lapangan: (1) Menambah pemasukan karena bertambahnya tawaran pekerjaan show; (2) Membuka kesempatan untuk bertemu dengan berbagai kalangan masyarakat seperti pengusaha dan atau

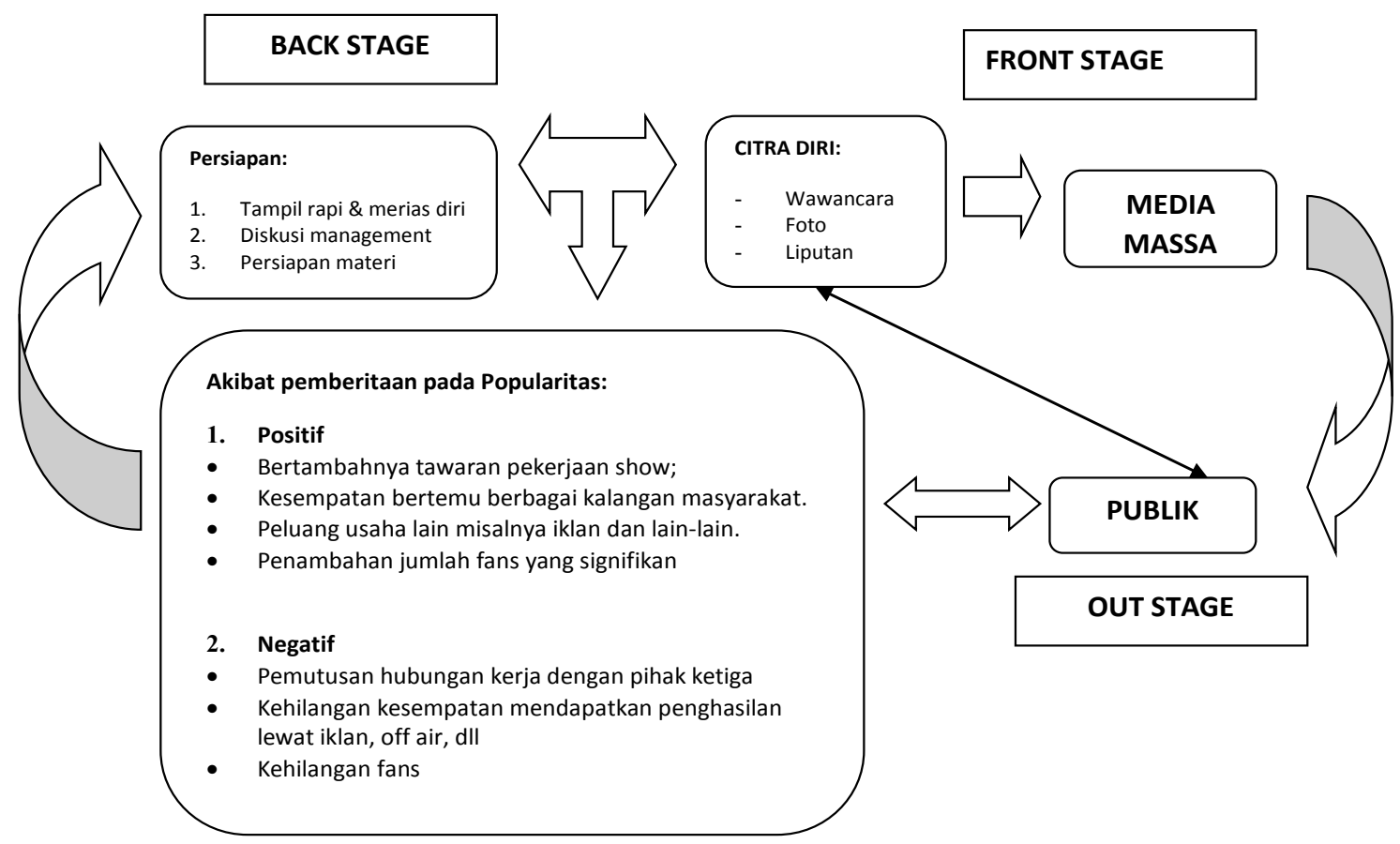

Gambar 4 Model Citra Diri Artis di Media Massa dan Popularitasnya di Publik 
pejabat publik, (3) Membuka peluang usaha lain diluar industri hiburan untuk menambah pemasukan pribadi, misalnya iklan, dan lainlain, serta (4) Penambahan jumlah fans yang signifikan.

Artis sangat memahami bahwa profesinya sebagai penghibur di industri hiburang sangat berkorelasi erat dengan pencitraan. Semakin baik citra diri yang ditampilkan, maka semakin positif respon yang akan didapat dari publik. Hal ini akan berdampak pada popularitas yang akan semakin tinggi di kalangan masyarakat.

Artis menempati kelas yang berbeda di tengah masyarakat. Artis seringkali dianggap sebagai kelompok eksklusif, yang tidak mudah didekati oleh masyarakat biasa. Oleh sebab itu, artis dianggap sebagai sosok yang menjadi rujukan bagi berbagai trend yang hidup ditengah masyarakat. Misalnya trend fashion, gaya hidup, dan lain-lain. Trend tersebut dikelola oleh artis dengan menempatkannya di dalam diri sendiri, sehingga muncul citra diri seperti yang diinginkan publik.

Selain itu, artis sangat memahami peran media untuk perkembangan karirnya. Banyak artis yang kemudian memanfaatkan media massa untuk berbagai tujuan seperti menaikkan reputasi, membuat sensasi agar namanya tetap populer, atau memanfaatkan media sebagai media promosi untuk kepentingan bisnisnya, dan lain-lain. Semakin banyak sorotan yang ditujukan media kepada mereka, semakin mendongkrak popularitas sang artis. Popularitas ini yang kemudian menjadi modal bagi artis tersebut untuk mendapatkan tawaran manggung dan atau penawaran kesempatan lain yang memberikan keuntungan secara finansial. Oleh sebab itu, artis seringkali menuntut dirinya sendiri untuk kooperatif dengan media massa.

Hal ini memang tidak berlaku untuk artis senior yang citra dirinya jauh lebih ajeg daripada artis yunior. Mereka cenderung menampilkan citra diri yang sesungguhnya. Citra diri itulah yang kemudian dibawa ke ranah publik melalui media massa, yang berdampak pada popularitas artis yang bersangkutan.

\section{SIMPULAN}

Citra diri bagi artis menentukan kesan yang ingin dibentuk dalam media massa. Semakin baik citra diri yang ditampilkan, maka peluang untuk mendapatkan kesan yang baik di media massa juga akan tercapai. Hal ini sejalan dengan pernyataan jika tidak semua orang mempunyai pengaruh yang sama terhadap citra diri artis. Yang paling mempengaruhi citra diri artis adalah orang-orang sekitar yang membawa berinteraksi dengan dirinya, karena interaksi tersebutlah yang akan menjadi realita. Realita tersebut harus mampu dibingkai artis menjadi bagian dari citra dirinya. Jika bingkai citra diri yang ditampilkan tidak sesuai dengan realita, maka suatu saat ketika realita tersebut terbuka, artis akan mendapat publikasi yang buruk. Tetapi jika citra diri yang ditampilkannya positif, maka dampak positiflah yang akan diperoleh artis pada kehidupan personalnya.

Sebelum berhadapan dengan wartawan untuk diwawancara, artis melakukan beberapa persiapan, diantaranya tampil rapi dan merias diri, menenangkan diri agar berada dalam kondisi emosi yang stabil, dan berdiskusi dengan manajemen untuk menampilkan citra diri yang positif di hadapan wartawan. Ketika berhadapan dengan wartawan, maka artis melakukan berbagai upaya, diantaranya berusaha selalu tersenyum dan dalam kondisi emosi yang stabil ketika bertemu wartawan, berusaha mengatur ritme pembicaraan ketika berbincang-bincang dengan wartawan, sehingga setiap pernyataan yang diucapkan dapat ditangkap dengan jelas oleh wartawan, dan berusaha mengatur kalimat sehingga kalimat yang dikatakan cukup bijaksana.

Artis memahami sepenuhnya makna popularitas bagi dirinya. Popularitas yang positif akan menghasilkan dampak positif, diantaranya bertambahnya tawaran pekerjaan, off air, kesempatan bertemu berbagai kalangan masyarakat seperti pengusaha dan atau pejabat publik, peluang mendapatkan kesempatan menambah penghasilan lain misalnya iklan, dan lain-lain, juga penambahan jumlah fans yang signifikan. Sementara jika popularitas negatif yang didapat maka akan berdampak pada pemutusan hubungan kerja dengan pihak ketiga, kehilangan kesempatan mendapatkan penghasilan lewat iklan, off air, dan pemasukan lain-lain, kehilangan fans.

Citra diri yang ditampilkan oleh artis, jika dibingkai secara positif oleh wartawan dalam berita di media massa, maka akan memberi kesan positif juga oleh publik. Jika sebaliknya, maka publik juga yang akan menolaknya. Berita di media massa membawa dampak popularitas 
yang besar bagi artis. Artis membutuhkan popularitas untuk dapat bertahan dalam menjalankan profesinya. Selain itu, artis juga mendapatkan berbagai keuntungan baik secara materi maupun immateriil sebagai dampak dari popularitas yang diperolehnya. Oleh sebab itu, artis selalu berupaya memelihara hubungan baik dengan wartawan sebagai mitra kerjanya.

Berdasarkan simpulan dan pembahasan pada uraian sebelumnya, maka saran-saran yang diberikan peneliti terhadap artis adalah: (1) Artis harus cerdik dalam menjaga citra dirinya, dan cerdik dalam mengelola popularitas yang sudah diraih. Artis harus mampu menjaga integritasnya agar publik tidak merasa ditipu. Oleh sebab itu, artis perlu menjauhkan diri dari perbuatan-perbuatan buruk atau gaya hidup salah yang mungkin akan diketahui publik, (2) Artis dihimbau untuk terus menerus melatih diri dalam membentuk citra diri yang ingin dicapai. Jangan terlena dengan pengalaman. Meminta bantuan kepada konsultan komunikasi bisa menjadi alternatif untuk menentukan citra diri yang lebih positif, (3) Popularitas tidak harus menjadi sasaran akhir yang wajib diraih, tetapi juga dapat berarti sebagai dampak dari kerja keras dan totalitas dalam berkarya. Semakin baik karya yang dihasilkan, maka akan semakin baik pula dampaknya terhadap popularitas artis yang bersangkutan, (4) Artis harus memiliki kerja sama yang baik dengan seluruh wartawan. Oleh sebab itu, akan lebih baik jika artis dapat menyediakan waktu khusus untuk berinteraksi dengan wartawan, diluar pekerjaan masingmasing, dan (5) Wartawan dan media massa dihimbau untuk dapat membingkai berita dengan objektif sesuai dengan fakta yang ditemui di lapangan. Media massa juga diharapkan memperhatikan aspek keberimbangan dalam penulisan berita, sehingga artis tidak selalu menjadi objek penderita dalam berita.

\section{DAFTAR PUSTAKA}

Ardianto, E., dkk. (2007). Komunikasi massa suatu pengantar. Edisi Revisi Bandung: Simbiosa Rekatama Media.

Creswel, J. W. (1998). Qualitative inquiry and research design, choosing among five traditions. California: Sage Publications, Inc.

Haryatmoko. (2007). Etika komunikasi, manipulasimedia, kekerasan, dan pornografi. Yogyakarta: Kanisius

Kuswarno, E. (2009). Fenomenologi, konsepsi, pedoman, dan contoh penelitian. Bandung: Widya Padjadjaran

Moleong, L. J. (2006). Metodologi penelitian kualitatif. Bandung: Remaja Rosda Karya.

Mulyana, D. (2006). Metodologi penelitian kualitatif: paradigma baru ilmu komunikasi dan ilmu sosial lainnya. Bandung: Remaja Rosdakarya

Poloma, M. M. (2010). Sosiologi kontemporer. Jakarta: Raja Grafindo Perkasa

Rakhmat, J. (2001). Metode penelitian komunikasi. Bandung: Remaja Rosdakarya

Severin \& Tankard Jr. (2007). Teori komunikasi, sejarah, metode, dan terapan di dalam media massa. Jakarta: Kencana Prenada Media Group. 